\title{
LEUKOCYTAPHERESIS IN THE MANAGEMENT OF SEVERE STEROID-DEPENDENT ULCERATIVE COLITIS
}

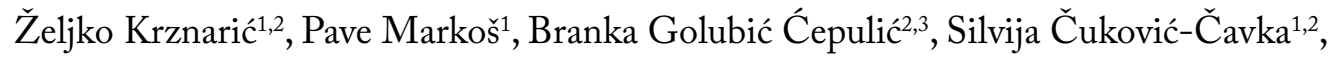 \\ Viktor Domislović ${ }^{1}$ Ines Bojanić ${ }^{2,3}$, Ana Barišić ${ }^{1}$ and Domina Kekez ${ }^{4}$ \\ ${ }^{1}$ Zagreb University Hospital Centre, Department of Gastroenterology and Hepatology, Zagreb, Croatia; \\ ${ }^{2}$ School of Medicine, University of Zagreb, Zagreb, Croatia; \\ ${ }^{3}$ Department of Transfusion Medicine and Transplantation Biology, Zagreb University Hospital Centre, \\ Zagreb, Croatia; \\ ${ }^{4}$ Department of Oncology, Zagreb University Hospital Centre, Zagreb, Croatia
}

\begin{abstract}
SUMMARY - Ulcerative colitis (UC) is a multifactorial disease of unknown precise etiology and immunopathogenesis. Peripheral blood granulocytes and monocytes/macrophages are the major sources of cytokines, which regulate inflammation. Leukocytapheresis (LCAP) is a method where blood is processed by apheresis system that removes lymphocytes and plasma before being returned to the body. We report the first case in Croatia where we used LCAP in the treatment of a patient with severe steroid-dependent UC. After 12 LCAP procedures, good clinical response was obtained and there were no significant adverse side effects noticed. The patient remained in clinical remission over two years in which he underwent regular follow ups at outpatient clinic. Over a 10-year follow-up period after LCAP, the patient had only occasional clinical symptoms of disease activity. The clinical course was complicated with the development of metastatic colorectal carcinoma, which points to the importance of regular disease monitoring rather than the increased risk of malignant disease after LCAP. Patients with UC are a demanding group of patients that warrant the search for novel treatment strategies other than conventional pharmacological therapies. Although LCAP is still not a common treatment modality in our daily practice, data from recent studies suggest it to be an effective and safe procedure in the management of active UC patients.
\end{abstract}

Key words: Leukapheresis; Colitis, ulcerative; Colorectal neoplasms; Croatia; Case reports

\section{Introduction}

Ulcerative colitis (UC) is a chronic inflammatory condition characterized by continuous mucosal inflammation, which is affecting the rectum and to a variable extent the colon. The disease course is relapsing and remitting. Although the etiology and pathogenesis remain uncertain, results of the studies suggest that atypical immune response to an environmental trigger in a genetically predisposed person could be re-

Correspondence to: Prof. Željko Krznaric, $M D, P b D$, Zagreb University Hospital Centre, Department of Gastroenterology and Hepatology, Kišpatićeva 12, HR-10000 Zagreb, Croatia

E-mail: zeljko.krznaric1@zg.t-com.hr

Received February 25, 2019, accepted July 7, 2019 lated to the development of $\mathrm{UC}^{1}$. Medications used in the treatment of UC include anti-inflammatory drugs, steroids, immunosuppressive drugs and biological agents. These agents are used to induce and maintain remission and can have many side effects. Leukocytapheresis (LCAP), a method that removes leukocytes from the circulatory system, is a non-pharmacological therapeutic approach for active UC. The mechanism of action consists of removal of the cell population involved in bowel inflammation from peripheral blood, where circulating cytokines and specific inflammatory cells can be removed from blood by the use of specific filters ${ }^{2}$. Activated peripheral blood granulocytes are the source of many inflammatory cytokines, which are thought to be involved in the pathogenesis of UC. 
Activated peripheral granulocytes infiltrate the colonic mucosa where they interact with lymphocytes and initiate disease activity and relapse ${ }^{3-5}$. Bearing in mind those processes, it is thought that LCAP has the potential to reduce inflammation, and possibly lead to reduction of steroid use in the management of patients with UC.

Different apheresis techniques have different adsorption capacities and remove different types of leukocytes. There are two most common techniques that involve removal of specific cells from the blood, using special filter of nonwoven polyester fibers (Cellsorba, Asahi Kasei Medical Company, Tokyo, Japan) or column containing cellulose acetate beds (Adacolumn, Jimro, Takasaki, Japan $)^{6}$. Blood is drawn via a venous catheter, passed through the system where leukocyte adhere, and thereafter returned into the circulatory system. There are several recently published studies that showed LCAP to be a safe and effective therapeutic option for active $\mathrm{UC}^{2,7}$. We present a case of a patient with severe UC and refractory anemia who was, for the first time in Croatia, treated with LCAP.

\section{Methods}

Leukocytapheresis serves for removal of plasma and mononuclear cells from the blood. We used the COBE Spectra apheresis system (Software Version 6.1; Terumo BCT, Lakewood, USA) according to the COBE Spectra therapeutic apheresis guide protocol. For anticoagulation, citrate dextrose solution-A (ACD-A) was used. The blood flow was $47 \mathrm{~mL} / \mathrm{min}$. During each LCAP cycle, a total of $7502 \pm 1047 \mathrm{~mL}$ blood (1.5 x total blood volume) was processed and $627.8 \pm 87.2 \mathrm{~mL}$ of ACD-A was used. The mean number of lymphocytes removed was $2.02 \pm 0.76 \times 10^{9}$, and a total of $2100 \pm 636 \mathrm{~mL}$ plasma was removed, which was $50 \%-55 \%$ of the patient's total plasma volume. Removed plasma was replaced with $5 \%$ albumin in saline.

\section{Case Report}

A 27-year-old male patient was admitted to the Zagreb University Hospital Centre in April 2007 due to UC relapse and severe secondary anemia. Initially, UC was diagnosed in 2005 at the Split University Hospital Centre. Therapy with mesalazine was started and positive clinical response was achieved. In October
2005 , the patient was admitted to the hospital due to severe relapse of ulcerative pancolitis, therefore steroids were introduced in therapy. Subsequently, azathioprine at a dose of $2 \mathrm{mg} / \mathrm{kg} /$ day was started and the dose of steroid was gradually reduced. In November 2006, the patient presented with maculopapulous rash in axillary region, groin and trunk. Dermatologists suggested these lesions to be side effects of steroids. In February 2007, the patient was referred to the Outpatient Clinic for Inflammatory Bowel Diseases, Zagreb University Hospital Centre. Therapy with mesalazine $4 \times 1 \mathrm{~g}$, azathioprine $2 \mathrm{mg} / \mathrm{kg} /$ day and gradual reduction of steroid dose was recommended. Upon steroid reduction, the patient's clinical symptoms worsened again and he was hospitalized in March 2007 at Department of Gastroenterology and Hepatology, $\mathrm{Za}$ greb University Hospital Centre. Conservative measures of treatment led to short-term clinical improvement, but already in April 2007, the patient was admitted to our Department due to relapse of the disease and severe secondary anemia. The patient was admitted to the hospital in extremely poor general condition, with tachycardia, up to 10 bloody watery stools per day, abdominal pain, and a history of weight loss of about $15 \mathrm{~kg}$ in the past year. Laboratory analysis revealed increased inflammatory markers (erythrocyte sedimentation rate $150 \mathrm{~mm} / \mathrm{h}, \mathrm{C}$-reactive protein 68 $\mathrm{mg} / \mathrm{L})$ and severe anemia (E $1.81 \times 10^{12}, \mathrm{Hb} 51 \mathrm{~g} / \mathrm{L}$, MCV 90.6 fl, MCH 29.1 pg). Intra-abdominal abscess collection and gastrointestinal infection were excluded by initial examinations, while native rectosigmoidoscopy showed entirely hyperemic and friable rectal mucosa, ulcerations covered with fibrin, spontaneous bleeding and pseudopolyps. Mayo Score was 10 (of maximum 12), which altogether suggested the diagnosis of severe pancolitis (Mayo Endoscopic Score (MES) 3) (Fig. 1). Therefore, we started therapy with intravenous steroids (methylprednisolone $60 \mathrm{mg}$ ).

Due to a steroid-dependent disease, previously described side effects to steroid therapy and inadequate response to azathioprine, we suggested biological therapy (infliximab). The patient refused biological therapy, as well as colectomy, so we decided to start with LCAP as a treatment procedure. The patient was treated according to the following scheme: initially twice a week for two weeks, then once a week for a month, and then, depending on the success of therapy, maintenance therapy once a month. During hospital stay, the pa- 


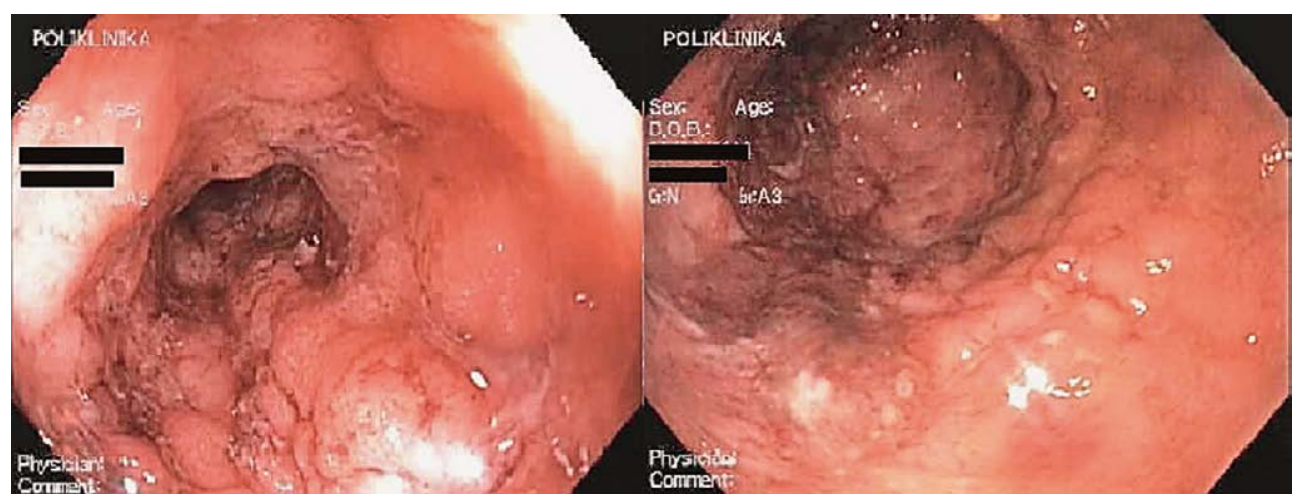

Fig. 1. Rectosigmoidoscopy before leukocytapheresis - Mayo Score 3: edema, spontaneous bleeding, ulcerations, pseudopolyps.

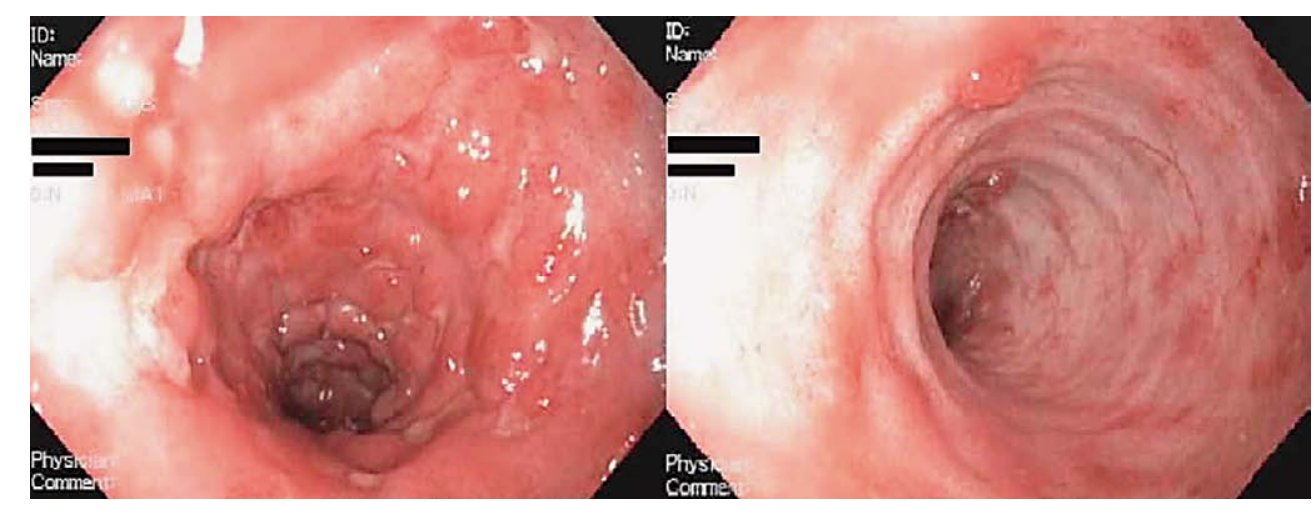

Fig. 2. Rectosigmoidoscopy after leukocytapheresis - Mayo Score 1: erythema, decreased vascular pattern, mild friability, pseudopolyps.

tient underwent three LCAP cycles. There was no side effects observed, while clinical and laboratory improvement was achieved. At discharge, the patient had 3-4 stools per day without a tinge of mucus or blood. The value of Mayo Score was 4 (MES 1) (Fig. 2). Anemia was corrected by transfusion of red blood cell (RBC) concentrate (a total of $2100 \mathrm{~mL}$ ). After discharge from the hospital, therapeutic LCAP was continued in an outpatient setting by the previously described scheme. The patient's condition remained stable, the number of stools was two to three formed stools daily, with no pathologic tinge. The patient was afebrile and had a body weight increase of $4 \mathrm{~kg}$ and MES around 2-3. The inflammatory parameters remained within the reference intervals, while anemia was corrected by transfusion of RBC concentrate two times (per $570 \mathrm{~mL}$ ). The patient underwent a total of 12 therapeutic procedures during three months. Changes in the CRP levels during that period are shown in Figure 3, and changes in hemoglobin levels in Figure 4. In addition, therapy with mesalazine $4 \mathrm{~g}$ and azathioprine $2 \mathrm{mg} / \mathrm{kg} /$ day with nutritional support (polymeric enteral nutritional supplement 1.5 $\mathrm{kcal} / \mathrm{mL}, 1-2$ packages per day) was continued. There was no need for steroid therapy. Refractory anemia was thought to be a side effect of azathioprine, therefore this drug was excluded from therapy. However, laboratory tests still indicated persistence of secondary anemia and persistence of slightly elevated inflammatory parameters (CRP $24 \mathrm{mg} / \mathrm{L}$ ). Two years after the end of LCAP, the patient's clinical condition was stable while taking mesalazine, the patient had constant body weight and was afebrile with 2-3 formed stools daily with no pathologic tinge. Over the next six years, the patient refused regular disease monitoring or colonoscopy and did not refer to our outpatient clinic. He was hospitalized again in 2015, but this time due to appendicitis with appendicular abscess. At this point, we found out that the patient had not been taking his medical therapy for several years, and had failed to 


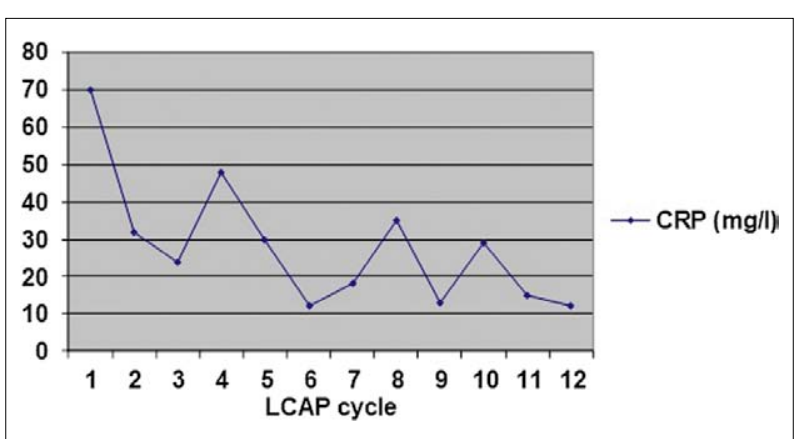

Fig. 3. $C$-reactive protein (CRP) levels $(\mathrm{mg} / \mathrm{L})$ during leukocytapheresis (LCAP) cycles.

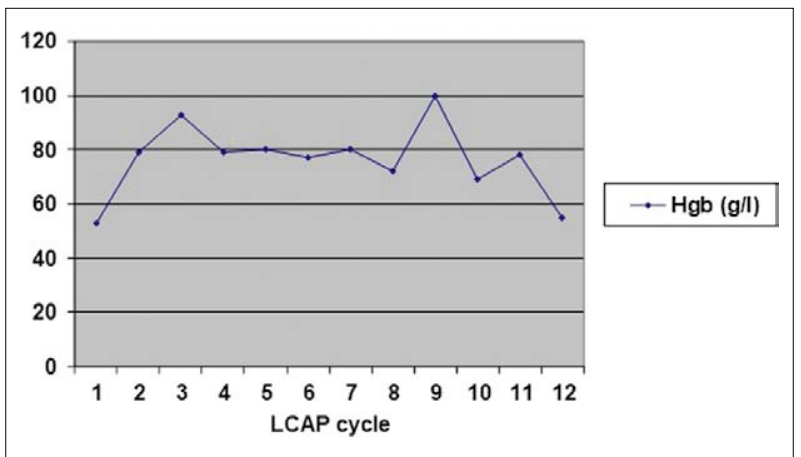

Fig. 4. Hemoglobin levels $(g / L)$ during leukocytapheresis (LCAP) cycles.

present for regular follow up examinations (last colonoscopy performed in 2007), despite occasionally having clear symptoms and signs of disease activity. After refusing further medical treatment and endoscopic reevaluation, he was hospitalized again in 2017, but this time due to perforation of the colon. The patient underwent emergency surgery, which revealed transverse colon stenosis; therefore, subtotal colectomy was performed. Histopathologic analysis confirmed adenocarcinoma of the colon with positive malignant cells in local lymph nodes and lymphovascular invasion (Dukes C, Modified Aster-Coller C2, TNM classification $\mathrm{pT} 3 \mathrm{~N} 2 \mathrm{bMx}$ ). The tumor was a microsatellite stable tumor. Positron-emission tomographycomputed tomography scan showed pathologic accumulation in the liver and mediastinal and cervical lymph nodes. Due to metastatic carcinoma of the $\mathrm{co}^{-}$ lon, until now the patient received 10 cycles of a combination of bevacizumab with FOLFIRI regimen, had laboratory findings in the reference range and was feeling well.

\section{Discussion}

Leukocytapheresis is a method that is used in many clinical conditions, mainly in autoimmune related disorders, such as multiple sclerosis, dermatomyositis and rheumatoid arthritis 8 . There are two basic methods for extracorporeal removal of leukocytes, i.e. centrifugal and adsorptive methods. Adsorptive cytapheresis is a therapeutic procedure in which patient's blood is passed through a medical device, which contains a column or filter that selectively adsorbs activated monocytes and granulocytes. In centrifugal method, blood cells are separated based on their specific gravity, and both leukocytes and plasma that contains inflammatory cytokines are removed ${ }^{9}$. Adsorptive method has proved to be effective and includes granulocyte and monocyte/macrophage adsorptive apheresis (GMCAP) and LCAP. GMCAP removes about 65\% granulocytes, $55 \%$ monocytes, and a very small number of lymphocytes, whereas LCAP removes about $100 \%$ granulocytes and $61 \%$ lymphocytes ${ }^{6,10}$. LCAP also removes about $30 \%$ of activated platelets that can help the process of tissue repair ${ }^{11}$. Significant difference between the efficiency of LCAP and GMCAP has not been demonstrated ${ }^{12}$. According to current apheresis guidelines, selective apheresis is a potentially useful adjunct for the management of inflammatory bowel disease with the goal of removing activated leukocytes or moderating their proinflammatory nature towards an immune modulatory phenotype ${ }^{13}$. Based on recent clinical studies, three basic mechanisms by which LCAP shows its therapeutic action have been established: (a) reduction of the number of activated lymphocytes and dendritic cells; (b) weakening the function of dendritic cells; and (c) reduction of the levels of proinflammatory cytokines (TNF- $\alpha$, IL-1b, IL-6, IL-8, IFN $\gamma$ ).

Many studies have been conducted to evaluate the safety and efficacy of cytapheresis in the induction of remission in patients with UC. However, in most of these studies, small numbers of patients were included. Furthermore, there is a lack of randomized controlled trials, which could evaluate the effect of LCAP in the management of UC. Data from uncontrolled studies showed a high response rate in corticosteroid-naive patients and remission rate of $50 \%$ in patients with steroid-dependent or steroid-refractory UC ${ }^{14-20}$. Studies have shown that LCAP not only improves clinical 
symptoms but also is effective in the induction of mucosal healing ${ }^{21}$. Data from most of the trials showed that adverse side effects were much less frequent in patients treated with LCAP than those treated with steroids. An open-label multicenter randomized control study and a double-blind, prospective, case-controlled study with sham apheresis as placebo treatment demonstrated the safety and efficacy of LCAP for treating active $\mathrm{UC}^{10,22}$. A large-scale prospective, observational study by the Japanese group of authors showed LCAP to be a safe and effective therapeutic option for active UC. Clinical remission was achieved in $68.9 \%(429 / 623)$ of patients, while $62.5 \%(145 / 232)$ of patients had mucosal healing. Patients having undergone intensive LCAP ( $\geq 4$ LCAP sessions within the first 2 weeks) achieved clinical remission more rapidly and frequently than patients in the weekly group. In addition, $10.3 \%$ (87/847) of patients had mild adverse events and severe adverse events were observed in only $5(0.6 \%)$ patients $^{23}$. Although there is evidence that LCAP is effective treatment for the induction of remission, it has not shown such a good effect when used as maintenance therapy ${ }^{24}$. However, a recent multicenter, retrospective, observational study of clinical outcomes and risk factors for UC relapse at 1 year after LCAP showed the 1-year cumulative relapse-free rate in the majority of patients $(63.6 \%)^{25}$. In our severely steroid-dependent patient with UC, we observed fast response to therapy and improvement of general condition, clinical symptoms and signs, and laboratory parameters. There were no adverse effects, which is consistent with literature data on larger patient samples. In addition, our patient remained in clinical remission for two years, in which period he paid regular follow up visits to outpatient clinic. Interestingly, over a 10-year follow up after LCAP, the patient had only occasional clinical symptoms of disease activity, without the need for hospital treatment. Development of metastatic carcinoma of the colon points to the importance of regular disease monitoring and endoscopic evaluation, which was not performed for approximately 10 years due to the patient's noncompliance rather than the increased risk of malignant disease after LCAP, which has not been described in the literature. Patients with UC are a demanding group of patients that warrant search for novel treatment strategies other than conventional pharmacological therapies. Although LCAP is still not a common treatment modality in our daily practice, data from recent studies suggest it to be an effective and safe procedure in the management of active UC patients. Larger studies are needed to show long-term beneficial effects of this therapy.

\section{References}

1. Magro F, Gionchetti P, Eliakim R, et al. Third European evidence-based consensus on diagnosis and management of ulcerative colitis. Part 1: Definitions, diagnosis, extra-intestinal manifestations, pregnancy, cancer surveillance, surgery, and ileo-anal pouch disorders. J Crohns Colitis. 2017;11(6):649-70, http://dx.doi.org/10.1093/ecco-jcc/jjx008

2. Gerçeker E, Yüceyar H, Kasap E, et al. Treatment of inflammatory bowel disease by leukocytapheresis. Transfus Apher Sci. 2017;56(3):421-6, http://dx.doi.org/10.1016/j.transci.2017.03.016

3. Papadakis KA, Targan SR. Role of cytokines in the pathogenesis of inflammatory bowel disease. Annu Rev Med. 2000; 51(1):289-98. doi: 10.1146/annurev.med.51.1.289

4. Nikolaus S, Bauditz J, Gionchetti P, et al. Increased secretion of pro-inflammatory cytokines by circulating polymorphonuclear neutrophils and regulation by interleukin 10 during intestinal inflammation. Gut. 1998;42(4):470-6, http://dx.doi.org/ 10.1136/gut.42.4.470

5. Kanai T, Makita S, Kawamura T, et al. Extracorporeal elimination of TNF- $\alpha$-producing CD14 ${ }^{\text {dull }} \mathrm{CD} 16^{+}$monocytes in leukocytapheresis therapy for ulcerative colitis. Inflamm Bowel Dis. 2007;13(3):284-90, http://dx.doi.org/10.1002/ibd.20017

6. Saniabadi AR, Hanai H, Takeuchi K, et al. Adacolumn, an adsorptive carrier based granulocyte and monocyte apheresis device for the treatment of inflammatory and refractory diseases associated with leukocytes. Ther Apher Dial. 2003;7(1):48-59.

7. Komoto S, Matsuoka K, Kobayashi T, et al. Safety and efficacy of leukocytapheresis in elderly patients with ulcerative colitis: the impact in steroid-free elderly patients. J Gastroenterol Hepatol. 2018;33(8):1485-91, http://dx.doi.org/10.1111/jgh.14116

8. Helmy A, Abdulla M, Kagevi I, et al. Leukocyte apheresis in the management of ulcerative colitis. Saudi J Gastroenterol. 2009; 15(4):283-7, http://dx.doi.org/10.4103/1319-3767.56093

9. Liumbruno GM, Centoni PE, Niccoli G, et al. A case report of long-term remission of ulcerative colitis after lymphocytoplasmapheresis. Ther Apher Dial. 2007 Feb;11(1):65-9, http:// dx.doi.org/10.1111/j.1744-9987.2007.00456.x

10. Sawada K, Kusugami K, Suzuki Y, et al. Leukocytapheresis in ulcerative colitis: results of a multicenter double-blind prospective case-control study with sham apheresis as placebo treatment. Am J Gastroenterol. 2005;100(6):1362-9, http://dx.doi. org/10.1111/j.1572-0241.2005.41089.x

11. Yagi Y, Andoh A, Inatomi O, et al. Modulation of platelet aggregation responses by leukocytapheresis therapy in patients 
with active ulcerative colitis. J Gastroenterol. 2006;41(6):540-6, http://dx.doi.org/10.1007/s00535-006-1797-y

12. Sakata $\mathrm{Y}$, Iwakiri R, Amemori S, et al. Comparison of the efficacy of granulocyte and monocyte/macrophage adsorptive apheresis and leukocytapheresis in active ulcerative colitis patients: a prospective randomized study. Eur J Gastroenterol Hepatol. 2008;20(7):629-33, http://dx.doi.org/10.1097/ MEG.0b013e3282f5e9a4

13. Schwartz J, Padmanabhan A, Aqui N, et al. Guidelines on the use of therapeutic apheresis in clinical practice - evidence-based approach from the Writing Committee of the American Society for Apheresis: the Seventh Special Issue. J Clin Apher. 2016 Jun;31(3):149-62, http://dx.doi.org/ doi: 10.1002/ jca. 21470

14. Hanai H. Positions of selective leukocytapheresis in the medical therapy of ulcerative colitis. World J Gastroenterol. 2006; 12(47):7568-77, http://dx.doi.org/10.3748/wjg.v12.i47.7568

15. Hanai H, Iida T, Takeuchi K, et al. Intensive granulocyte and monocyte adsorption versus intravenous prednisolone in patients with severe ulcerative colitis: an unblinded randomised multi-centre controlled study. Dig Liver Dis. 2008;40(6): 433-40, http://dx.doi.org/10.1016/j.dld.2008.01.007

16. Yamamoto T, Umegae S, Matsumoto K. Safety and clinical efficacy of granulocyte and monocyte adsorptive apheresis therapy for ulcerative colitis. World J Gastroenterol. 2006;12 (4):520-5, http://dx.doi.org/10.3748/wjg.v12.i4.520

17. Shiraki M, Yamamoto T. Steroid-sparing strategies in the management of ulcerative colitis: efficacy of leukocytapheresis. World J Gastroenterol. 2012;18(41):5833-8, http://dx.doi. org/10.3748/wjg.v18.i41.5833

18. Tominaga K, Nakano M, Hoshino M, et al. Efficacy, safety and cost analyses in ulcerative colitis patients undergoing granulocyte and monocyte adsorption or receiving prednisolone.
BMC Gastroenterol. 2013;13:41, http://dx.doi.org/10.1186/ 1471-230X-13-41

19. Kumagai M, Yamato Y, Maeda K, et al. Extracorporeal leukocyte removal therapy for patients with ulcerative colitis. Pediatr Int. 2007;49(4):431-6, http://dx.doi.org/10.1111/j.1442-200 X.2007.02392.x

20. Bresci G, Parisi G, Mazzoni A, et al. Treatment of patients with acute ulcerative colitis: conventional corticosteroid therapy (MP) versus granulocytapheresis (GMA): a pilot study. Dig Liver Dis. 2007;39(5):430-4, http://dx.doi.org/10.1016/j.dld. 2007.01.001

21. Okuyama Y, Andoh A, Nishishita M, et al. Multicenter prospective study for clinical and endoscopic efficacies of leukocytapheresis therapy in patients with ulcerative colitis. Scand J Gastroenterol. 2013;48(4):412-8. http://dx.doi.org/10.3109/0 0365521.2012 .763175

22. Sawada K, Muto T, Shimoyama T, et al. Multicenter randomized controlled trial for the treatment of ulcerative colitis with a leukocytapheresis column. Curr Pharm Des. 2003;9(4): 307-21. http://dx.doi.org/10.2174/1381612033391928

23. Yokoyama Y, Matsuoka K, Kobayashi T, et al. A large-scale, prospective, observational study of leukocytapheresis for ulcerative colitis: treatment outcomes of 847 patients in clinical practice. J Crohns Colitis. 2014;8(9):981-91. http://dx.doi. org/10.1016/j.crohns.2014.01.027

24. Honma T, Sugimura K, Asakura H, et al. Leukocytapheresis is effective in inducing but not in maintaining remission in ulcerative colitis. J Clin Gastroenterol. 2005;39(10):886-90. http:// dx.doi.org/10.1097/01.mcg.0000180638.59140.c5

25. Kobayashi T, Matsuoka K, Yokoyama Y, et al. A multicenter, retrospective, observational study of the clinical outcomes and risk factors for relapse of ulcerative colitis at 1 year after leukocytapheresis.J Gastroenterol.2018;53(3):387-96. http://dx.doi. org/10.1007/s00535-017-1356-8

\section{Sažetak}

\section{LEUKOCITAFEREZA U LIJEČENJU TEŠKOG, O STEROIDIMA OVISNOG ULCEROZNOG KOLITISA}

\section{Ž. Krznarić, P. Markoš, B. Golubić Ćepulic, S. Čuković-Čavka, V. Domislović, I. Bojanić, A. Barišici i D. Kekez}

Ulcerozni kolitis (UC) je kronična bolest multifaktorske etiologije čiji detaljan mehanizam imunološkog procesa još nije sasvim razjašnjen, ali ključnu ulogu svakako imaju granulociti i monociti/makrofazi koji reguliraju i pojačavaju upalni proces lučenjem proupalnih citokina. Leukocitofereza (LCAP) je terapijski postupak kojim se prolaskom krvi kroz sustav za aferezu odstranjuju limfociti i plazma prije nego što se krv ponovno vrati u krvotok. U ovom radu je prikazan o steroidima ovisan bolesnik s teškim relapsom UC-a koji je, prvi put u Hrvatskoj, liječen protokolom LCAP. Nakon 12 terapijskih protokola LCAP kod bolesnika je došlo do značajnog kliničkog poboljšanja bez razvoja nuspojava. Bolesnik je ostao u kliničkoj remisiji tijekom dvije godine ambulantnog praćenja, a unutar 10 godina praćenja nakon LCAP bolesnik je imao tek povremene simptome aktivnosti bolesti. Klinički tijek bio je kompliciran razvojem metastatskog karcinoma debelog crijeva, što prvenstveno upućuje na važnost redovitog praćenja bolesti, a ne na povećan rizik maligne bolesti nakon LCAP. Bolesnici s UC-om su zahtjevna skupina pacijenata koja zahtijeva potragu za novim terapijskim strategijama osim onih konvencionalnih farmakoloških. Iako LCAP nije čest modalitet liječenja u svakodnevnoj kliničkoj praksi, novije studije upućuju na to da je postupak učinkovit i siguran u liječenju bolesnika s aktivnim UC-om.

Ključne riječi: Leukafereza; Kolitis, ulcerozni; Kolorektalni tumori; Hrvatska; Prikazi slučaja 